Peer review: This article has been subject to a double blind peer review process

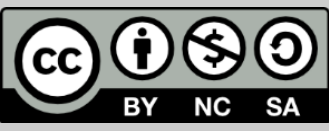

(c) Copyright: The Authors. This article is issued under the terms of the Creative Commons Attribution NonCommercial Share Alike License, which permits use and redistribution of the work provided that the original author and source are credited, the work is not used for commercial purposes and that any derivative works are made available under the same license terms.

\section{Asymmetric Exchange Rate Exposure - Research in Southeast Asian Countries}

\author{
Le Thi Hong Minh, Huynh Thi Cam Ha, Dinh Thi Thu Hong*
}

School of Finance, University of Economics Ho Chi Minh City, Vietnam

*Correspondence: honghtcdn@ueh.edu.vn

\begin{abstract}
The study aims to analyse the impact of exchange rate exposure on stock returns in six countries representative of Southeast Asia, including Indonesia, Malaysia, Philippines, Singapore, Thailand and Vietnam from 2009 to 2014. Both nominal and real exchange rates are taken into account for evaluating exchange rate fluctuations via panel data. In order to achieve this goal, a panel regressive estimation approach is proposed in which a GLS model is used to treat heteroskedasticity in the panel data and, then, a GMM estimator is employed to ensure the consistency of the estimates. The results point out that the exchange rate exposure of these countries is asymmetric. At the market level, for a rise in the exchange rate (or local currency depreciates), the average stock returns tend to decrease. However, due to the favourable impact of currency depreciation on the net export position, the reduction level of stock returns is faster than the rising level of the exchange rate.
\end{abstract}

Keywords: asymmetric exchange rate exposure, exchange rate risk, stock returns, stock market, Southeast Asia

\section{Introduction}

Exchange rate exposure caused by exchange rate risk is one of the most important factors in international asset pricing (Lin, 2011). In a world without barriers to international investors and while the products can be freely imported and exported between all countries, an asset will have the same price from wherever it is traded. In such cases, the asset-pricing model only includes the valuation of global factors.

In fact, markets are partly segmented (Bekaert and Harvey, 1995). This leads to variations of asset prices between markets and, therefore, an asset-pricing model sensitive to exchange rates is necessary (Hekman, 
1983; Adler and Dumas, 1984). In addition, due to the policy changes at the world's top financial centres (United States, United Kingdom and Europe) such as the quantitative easing policies issued after the financial crisis in 2008, a new capital investment was created and flowed into emerging markets. This generates currency fluctuations and subsequently, investors and multinational corporations are increasingly turning their gaze towards dynamic economic areas such as Southeast Asia. In recent years, ASEAN is constructing long-term infrastructures for the developing ASEAN capital market to enhance the market access, linkages, and liquidity. In 2014, the ASEAN Economic Community (AEC) was collectively the third largest economy in Asia and the seventh largest in the world. Under the AEC, the establishment of a huge regional common market of Asian countries in 2015 offers great opportunities for ASEAN. This integration objective is to create a competitive market with a total GDP of US\$2.6 trillion and over 622 million people in the following countries: Brunei, Cambodia, Indonesia, Laos, Malaysia, Myanmar, the Philippines, Singapore, Thailand, and Vietnam. To the best of the authors' knowledge, although several studies on currency risk exposures in emerging markets have been reported (Chue and Cook, 2007; Lin, 2011; Tsai, 2012), there is no such research concentrating on the exchange rate exposure of Southeast Asian stock markets. Hence, this study focuses on assessing the effects of exchange rate fluctuations on stock returns of security markets in Southeast Asia. The research aims to address two main questions: first, does the exchange rate exposure exist or does the exchange rate risk correlate with the stock returns volatility in the Southeast Asian countries? Second, is the exchange rate exposure symmetric or asymmetric?

\section{Literature review}

\subsection{The empirical research on the exchange rate exposure}

Many studies have been carried out to evaluate the exchange rate exposure by considering the sensitivity of stock returns to exchange rate changes (Hekman, 1983; Adler and Dumas, 1984). Follow-up studies on exchange rate exposure using this approach reported evidence of the presence of exchange rate exposure at market and firm levels but the results of these studies were not similar. For example, Lin (2011), Tsai (2012), Al-Shboul and Anwar (2014) all demonstrated a negative correlation between exchange rate fluctuations and stock returns throughout the study periods. Meanwhile, the research of Chue and Cook (2007) on 15 emerging markets showed that the exchange rate exposure did not exist in the period from 2002 to 2006. This was due to the change in the structure of regional bond markets with the increased 
market share from domestic bonds. Furthermore, the rapid development of the scale of currency derivative products also contributed to limiting exchange rate risks for investors. Ye et al. (2014) identified the existence of exchange rate exposure at $50 \%$ among 20 emerging markets, especially in countries applying pegged exchange rate regimes.

\subsection{Asymmetric exchange rate exposure}

Asymmetric exchange rate exposure implies that exchange rate fluctuations in the direction either of increasing or decreasing have different effects on firms' performance. In the study of Koutmos and Martin (2003) in Germany, Japan, Britain and the United States from 1992 to 1998 with monthly data series, the result pointed out that there existed the exchange rate exposure at the industrial level with approximately $40 \%$ of the samples, in which over $40 \%$ was asymmetric. At market level, the exchange rate exposure of these four countries could be represented by the profits of domestic market portfolios when the domestic currencies appreciated.

Recently, related research has been concentrated on countries with emerging economies. Lin (2011) paid attention to the Asian region after two periods of financial crisis in 1997 and 2008, specifically from July 1997 to November 2010. Herein, the real exchange rate was used to measure the changes in foreign exchange rates because the inflation in emerging markets was larger and more volatile than developed economies. The study also indicated that although the float exchange rate regime has been implemented and managed in emerging Asian countries, the exchange rate exposure remained significant, especially during the crisis periods due to the net exports position and/or dollar assets holdings. In another study, Bartram and Bodnar (2012) assessed the relationship between exchange rate exposure and stock returns based on samples of non-financial companies from 37 worldwide countries. It was found that there were significant differences in the impacts of the exchange rate exposure on stock returns between these countries. Around $30 \%$ to $40 \%$ of the sampled companies in the emerging markets (such as Brazil, South Africa, Indonesia, Argentina and Thailand) were sensitive to the exchange rate risks.

\section{Data and research methodology}

\subsection{Description of data}

In order to investigate the exchange rate exposure of Southeast Asian stock markets, six representative countries, including Indonesia, Malaysia, 
Philippines, Singapore, Thailand and Vietnam, were selected (because of underdeveloped stock markets in the rest of the region). The nominal exchange rates (quoted by indirect quotation or price quotation, named as USD/IDR, USD/MYR, USD/PHP, USD/SGD, USD/THB, USD/VND) and consumer price index CPI (base year 2010) of each country are extracted from the database IFS (International Financial Statistics) of the International Monetary Fund (IMF). This data set was then used to calculate the bilateral real exchange rate. In addition, $\mathrm{MSCl} A C W I$ (Morgan Stanley Capital International - All Country World Index) - a measure for world market returns and stock market indexes of six Southeast Asia countries - were taken from DataStream. Here, the data were collected monthly from January 2009 to December 2014, including 72 months and forming a panel data with 432 observations.

\subsection{Research methodology}

The study is based on the empirical methods used by Lin (2011). The standard model is applied to examine the exchange rate exposure as follows:

$R_{i, t}=\beta_{0}+\beta_{1} R_{W, t}+\theta X_{i, t}+\varepsilon_{i, t}$

where: $R_{W, t}$ is the world market portfolio returns, $R_{i, t}$ is the local market portfolio returns, $X_{i, t}$ is the exchange rate fluctuations $\left(X_{i, t}>0\right.$ represents foreign currency appreciation), $\varepsilon_{i, t}$ is the error term, and $\beta_{0}, \beta_{1}, \theta$ are the regression coefficients in which $\beta_{1}$ is the exposure to world market volatility and $\theta$ is the exchange rate exposure (a statistically significant value of $\theta$ implies that the exchange rate changes affect stock returns).

Because the standard model in equation (1) cannot be used to identify whether exchange rate exposure is symmetric or asymmetric, it is necessary to modify this model by splitting the vector $X_{i, t}$ into positive and negative components, denoted as $X_{i, t}^{+}=\operatorname{Max}\left(X_{i, t}, 0\right)$ and $X_{i, t}^{-}=\operatorname{Min}\left(X_{i, t}, 0\right)$, respectively. Equation (1) is then rewritten as follows:

$$
R_{i, t}=\beta_{0}+\beta_{1} R_{W, t}+\theta^{+} X_{i, t}^{+}+\theta^{-} X_{i, t}^{-}+\varepsilon_{i, t}
$$

Equation (2) can be used to examine whether the exchange rate exposure is symmetric, $H_{0}: \theta^{+}=\theta^{-}=\theta$, or asymmetric, $H_{1}: \theta^{+} \neq \theta^{-}$. Equation (2) can be represented as follows:

$$
R_{i, t}=\beta_{0}+\beta_{1} R_{W, t}+\left(\beta_{x}+\beta_{D, x} D_{i, t}\right) X_{i, t}+\varepsilon_{i, t}
$$

In particular, $\beta_{x}=\theta^{-}, \beta_{D, x}=\left(\theta^{+}-\theta^{-}\right), D_{i, t}=1$ if $X_{i, t}>0, D_{i, t}=0$ if $X_{i, t} \leq 0$. This formula is more intuitive and can be used directly to test the 
asymmetric hypothesis, $\mathrm{H}_{1}$. The asymmetric exchange exposure can be identified if $\beta_{\mathrm{D}, \mathrm{x}}$ is statistically significant, regardless of its sign. For a given value of the global market portfolio, exchange rate exposure is equal to $\beta_{\mathrm{x}}$ when $\mathrm{X}_{\mathrm{i}, \mathrm{t}} \leq 0$ and, conversely, equal to $\beta_{\mathrm{x}}+\beta_{\mathrm{D}, \mathrm{x}}$ when $\mathrm{X}_{\mathrm{i}, \mathrm{t}}>0$.

From the theoretical model in equation (3), the exchange rate exposure in the selected Southeast Asian countries is investigated using the following equations:

$$
\begin{aligned}
& \text { INDEX }_{i, t}=\beta_{0}+\beta_{1} \text { MSCIACWI }_{t}+\beta_{2} \text { NER }_{i, t}+\beta_{3} D_{i, t} * \operatorname{NER}_{i, t}+\varepsilon_{i, t} \\
& \text { INDEX }_{i, t}=\beta_{0}+\beta_{1} \text { MSCIACWI }_{t}+\beta_{2} \text { RER }_{i, t}+\beta_{3} D_{i, t} * \text { RER }_{i, t}+\varepsilon_{i, t}
\end{aligned}
$$

Table 1. Calculation of the variables in equations (4) and (5)

\begin{tabular}{|l|l|l|}
\hline Variables & Sign & Calculation \\
\hline Local market returns & INDEX & $\begin{array}{l}\text { Percentage change in monthly local stock } \\
\text { index }\end{array}$ \\
\hline $\begin{array}{l}\text { World market } \\
\text { returns }\end{array}$ & MSCIACWI & $\begin{array}{l}\text { Percentage change in monthly MSCI ACWI } \\
\text { index }\end{array}$ \\
\hline $\begin{array}{l}\text { Changing in Nominal } \\
\text { exchange rate }\end{array}$ & NER & $\begin{array}{l}\text { Percentage change in bilateral nominal } \\
\text { exchange rate (USD/local currency) }\end{array}$ \\
\hline $\begin{array}{l}\text { Changing in Real } \\
\text { exchange rate }\end{array}$ & RER & $\begin{array}{l}\text { Percentage change in bilateral real exchange } \\
\text { rate }\end{array}$ \\
\hline Dummy variable & D & $\begin{array}{l}\mathrm{D}=1 \text { if NER (or RER) }>0 \text { and D }=0 \text { for NER (or } \\
\text { RER) } \leq 0\end{array}$ \\
\hline
\end{tabular}

Unlike previous studies about exchange rate exposure, the panel data have been used instead of time-series data in this study. The reason is that from the existing data pool there is a limited number of observations in which the real exchange rate variable with monthly frequency is achievable. This problem can be solved by using the panel data regression. Moreover, according to Hsiao (1986) and Baltagi (2008), the use of panel data brings several advantages. First, compared to a typical cross-section or time-series data, a large data set with more variability and less collinearity among the variables is explored. Second, the more informative the data, the more reliable estimates and more sophisticated behavioural models with less restrictive assumptions we achieve. Another advantage of panel data use is the ability to control individual heterogeneity. Without controlling for the unobserved individual specific effects can result in biased estimates. Panel data sets also offer a high ability to identify and estimate effects that are not simply detectable while employing pure cross-sections or pure time-series data. 
Next, the exchange rate exposure analysis was performed by evaluating the impacts of exchange rate fluctuations on the stock returns through the panel data. The Stata software version 12 was selected for this study and the procedure of this regression analysis can be expressed as following steps:

- Step 1: Use the unit root tests presented by Levin-Lin-Chu (LLC Test 2002) and Im-Pesaran-Shin (IPS Test - 2003) to check the panel data stationary.

- Step 2: Regress the panel data using three methods: FEM (Fixed Effects Model), REM (Random Effects Model) and pooled OLS (Ordinary Least Squares). After that, the Likelihood ratio test, Hausman test and Breusch-Pagan Lagrangian multiplier test are applied to choose the most suitable model for the panel data.

- Step 3: Employ the GLS (Generalised Least Squares) estimator to compensate for the heteroskedasticity and/or autocorrelation in order to improve the model performance.

- Step 4: Utilise the GMM (Generalised Method of Moments) method to correct the endogeneity problem affecting the model consistency in order to validate the robustness of the estimation results.

\section{Research results and discussion}

\subsection{Descriptive statistics}

Table 2 presents the descriptive statistics for the monthly local market portfolio returns in Southeast Asia (INDEX), world market portfolio returns (MSCIACWI), bilateral nominal exchange rate change nominal (NER), and bilateral real exchange rate change (RER) of the research samples. From this table, during the period 2009-14, the average regional and global market stock returns were positive, but the regional stock return value was much higher and more volatile than the global one. The reason for this instability could be the effect of exchange rate fluctuations.

Table 2. Analysis on the descriptive statistics of variables

\begin{tabular}{|l|r|r|r|r|r|}
\hline \multicolumn{1}{|c|}{ Variable } & \multicolumn{1}{c|}{ Obs } & \multicolumn{1}{c|}{ Mean } & \multicolumn{1}{c|}{ Std. Dev. } & \multicolumn{1}{c|}{ Min } & Max \\
\hline INDEX & 432 & 0.0148969 & 0.0530967 & -0.1674 & 0.266786 \\
\hline MSCIACWI & 432 & 0.0095585 & 0.0472393 & -0.10023 & 0.114829 \\
\hline NER & 432 & 0.0005382 & 0.0189221 & -0.0745 & 0.092 \\
\hline RER & 432 & -0.0013259 & 0.0191211 & -0.0693 & 0.0831 \\
\hline
\end{tabular}


INDEX: local market returns, MSCIACWI: world market returns, NER: changing in nominal exchange rate, RER: changing in real exchange rate.

Obs: observations; Mean: average value; Std.Dev.: standard deviation; Min: minimum value; Max: maximum value.

The changes in the nominal exchange rate indicate that the average local currency fell against the dollar, but the average real exchange rate change was negative. It means that the local currency tended to rise as the consequence of the high inflation in the Southeast Asian countries and the large inflation differences between this region and the United States (Figure 1).

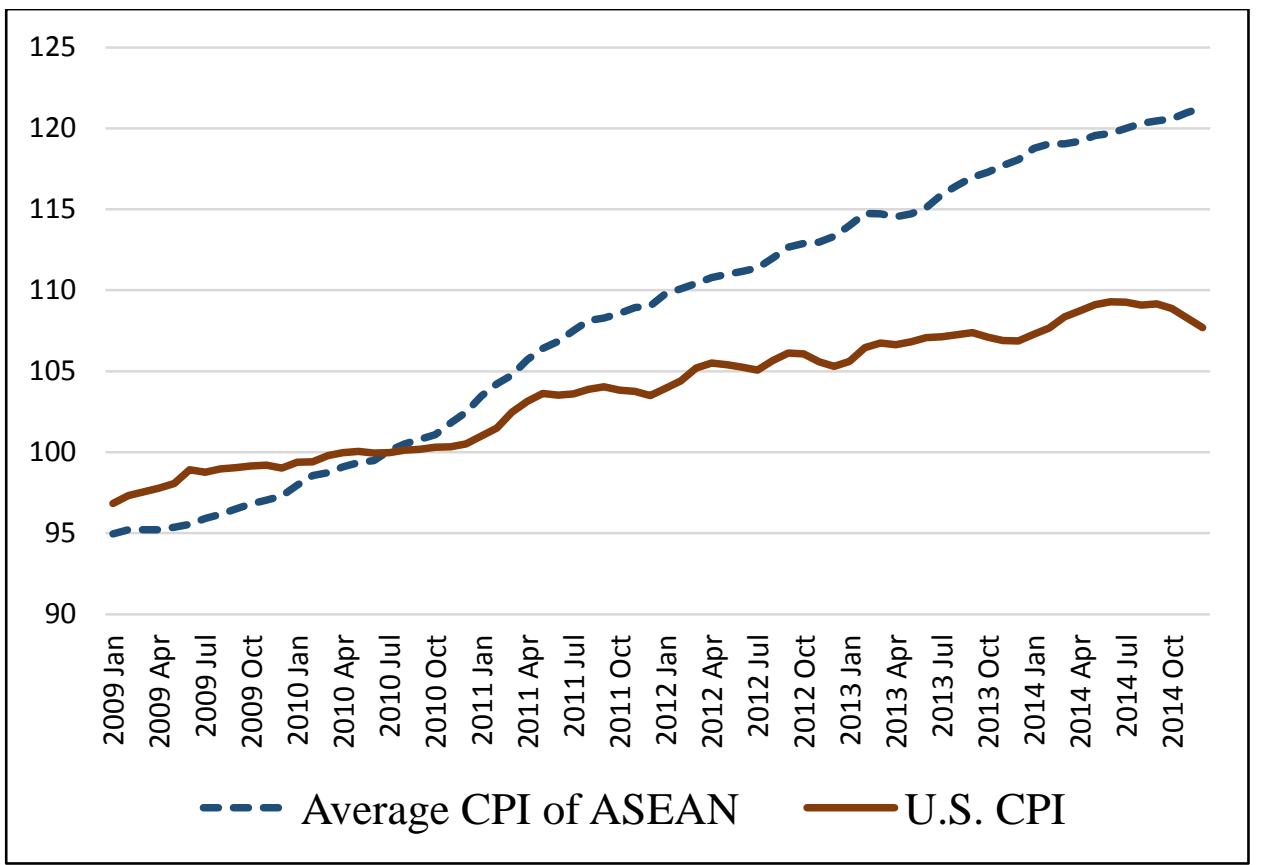

Figure 1. Average CPI of six Southeast Asian countries and U.S. CPI in the period 2009-14 $(2010=100)$

Source: IMF - IFS data

The results of Table 3 show the rejection of the unit root hypothesis at the significance level of $1 \%$ and all variables were stationary at level. This is the condition used to avoid spurious regression results. 
Table 3. Panel unit-root test results

\begin{tabular}{|l|r|r|r|r|}
\hline \multirow{2}{*}{ Variable } & \multicolumn{2}{|c|}{ LLC Test } & \multicolumn{2}{c|}{ IPS Test } \\
\cline { 2 - 5 } & Statistic & \multicolumn{1}{|c|}{$p$-value } & Statistic & $p$-value \\
\hline INDEX & -9.9258 & $0.0000^{* * *}$ & -12.2857 & $0.0000^{* * *}$ \\
\hline MSCIACWI & -13.4083 & $0.0000^{* * *}$ & -13.3193 & $0.0000^{* * *}$ \\
\hline NER & -11.2083 & $0.0000^{* * *}$ & -13.3259 & $0.0000^{* * *}$ \\
\hline D*NER & -8.5466 & $0.0000^{* * *}$ & -13.1209 & $0.0000^{* * *}$ \\
\hline RER & -12.7318 & $0.0000^{* * *}$ & -13.7210 & $0.0000^{* * *}$ \\
\hline D*RER & -9.6837 & $0.0000^{* * *}$ & -13.4399 & $0.0000^{* * *}$ \\
\hline
\end{tabular}

Notes: ${ }^{* * *}$ : Significant at the $1 \%$ level.

\subsection{The regression results}

\subsubsection{Exchange rate exposure with bilateral nominal exchange rate}

Table 4 presents the regression results of equation (4) which implied the impact of the nominal exchange rate fluctuations on the stock returns using the three models: pooled OLS, FEM and REM. The F-statistic value of Likelihood ratio test shows that the null hypothesis was acceptable and, the pooled OLS model provided a better fit than the FEM. The same results also could be obtained using the Chi-square value of BreuschPagan test.

To ensure the efficiency of the regression results, the homoscedasticity hypothesis and first-order autocorrelation were eliminated by using White test and Wooldridge test, respectively. 


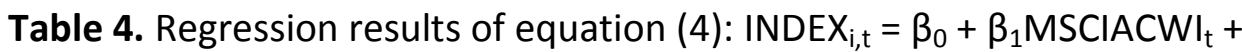
$\beta_{2} N R_{i, t}+\beta_{3} D_{i, t} * N E R_{i, t}+\varepsilon_{i, t}$

\begin{tabular}{|c|c|c|c|}
\hline Variable & Pooled OLS & FEM & REM \\
\hline MSCIACWI & $\begin{array}{l}0.3713566 * * * \\
(7.06)\end{array}$ & $\begin{array}{l}0.3691755^{* * *} \\
(7.00)\end{array}$ & $\begin{array}{l}0.3708143^{* * *} \\
(7.06)\end{array}$ \\
\hline / NER & $\begin{array}{l}-1.182976 * * * \\
(-4.93)\end{array}$ & $\begin{array}{l}-1.209624^{* * *} \\
(-4.75)\end{array}$ & $\begin{array}{l}-1.189308 * * * \\
(-4.90)\end{array}$ \\
\hline $\begin{array}{l}N \\
D^{*} \text { NER }\end{array}$ & $\begin{array}{l}0.6102628^{*} \\
(1.88)\end{array}$ & $\begin{array}{l}0.6385421^{*} \\
(1.83)\end{array}$ & $\begin{array}{l}0.6167636^{*} \\
(1.87)\end{array}$ \\
\hline $\begin{array}{l}N \\
\text { OConstant }\end{array}$ & $\begin{array}{l}0.0078913 * * * \\
(2.63)\end{array}$ & $\begin{array}{l}0.0077369 * * \\
(2.49)\end{array}$ & $\begin{array}{l}0.0078563^{* *} \\
(2.40)\end{array}$ \\
\hline$t \mathbf{R}^{2}$ & 0.2979 & 0.2978 & 0.2979 \\
\hline \multicolumn{2}{|c|}{$e_{\text {Likelihood ratio test }}$} & \multicolumn{2}{|c|}{ F statistic $=0.92$} \\
\hline \multicolumn{2}{|c|}{ Breusch-Pagan LM test } & \multicolumn{2}{|c|}{ Chi-Sq. Statistic $=0.16$} \\
\hline \multicolumn{2}{|l|}{ White test } & \multicolumn{2}{|c|}{ Chi-Sq. Statistic: $=28.79 * * *$} \\
\hline \multicolumn{2}{|c|}{ Wooldridge test } & \multicolumn{2}{|c|}{ F statistic $=0.005$} \\
\hline
\end{tabular}

statistic values are shown in parentheses; ***, **, and *, respectively, denote significance at the 1\%, 5\%, and 10\% level.

Table 5. Regression results of equation (4) by GLS

\begin{tabular}{|l|l|c|c|c|}
\hline Variable & Beta coefficient & Standard error & z-statistic & p-value \\
\hline MSCIACWI & $0.4284895^{* * *}$ & 0.0450748 & 9.51 & 0.000 \\
\hline NER & $-1.043651^{* * *}$ & 0.1908101 & -5.47 & 0.000 \\
\hline D*NER & $0.4855249^{*}$ & 0.2659888 & 1.83 & 0.068 \\
\hline Constant & $0.0077027^{* * *}$ & 0.0026295 & 2.93 & 0.003 \\
\hline
\end{tabular}

Notes: $t$-statistic values are shown in parentheses; $* * *, * *$, and $*$, respectively, denote significance at the 1\%,5\%, and 10\% levels.

Table 5 reports the results using the GLS model to treat the heteroskedasticity. The estimated results of coefficients indicate that the regional stock returns were positively affected by the changes in the global market stock returns. These results are consistent with the findings of Lin (2011). In particular, when the world stock returns increased $1 \%$, the local stock returns of the six Southeast Asian countries rose nearly $0.43 \%$. This was the consequence of opening trading markets for trade and investment. In terms of the trade openness (exports plus imports as a share of GDP) and criteria for assessing a country's integration into international trade, four among the six countries had the extremely high values of trade openness (over $120 \%$ as shown in Table 6). This was also the result of the capital account liberalisation to attract the 
foreign direct investment inflows, in which labour-intensive industries paid especial attention to the region's cheap labour. According to the Chinn-Ito index (KAOPEN), the degree of capital account openness was particularly high in the period 2000 to 2009 with an average value of 0.52 to 0.61 and fell to 0.39 from 2010 to 2013 in the general trend of capital controls after the 2008 financial crisis.

Table 6. The trade openness of the six ASEAN countries in the period 2009-2014

\begin{tabular}{|l|r|r|r|r|r|r|}
\hline \multicolumn{1}{|c|}{ Country } & \multicolumn{1}{c|}{$\mathbf{2 0 0 9}$} & \multicolumn{1}{c|}{$\mathbf{2 0 1 0}$} & \multicolumn{1}{c|}{$\mathbf{2 0 1 1}$} & \multicolumn{1}{c|}{$\mathbf{2 0 1 2}$} & \multicolumn{1}{c|}{$\mathbf{2 0 1 3}$} & \multicolumn{1}{c|}{$\mathbf{2 0 1 4}$} \\
\hline Indonesia & $35,79 \%$ & $40,92 \%$ & $46,11 \%$ & $44,53 \%$ & $49,51 \%$ & $43,69 \%$ \\
\hline Malaysia & $134,99 \%$ & $140,47 \%$ & $149,12 \%$ & $137,64 \%$ & $144,41 \%$ & $144,70 \%$ \\
\hline Philippines & $48,68 \%$ & $53,65 \%$ & $50,88 \%$ & $45,96 \%$ & $45,75 \%$ & $45,72 \%$ \\
\hline Singapore & $258,57 \%$ & $264,66 \%$ & $291,15 \%$ & $266,13 \%$ & $262,05 \%$ & $262,85 \%$ \\
\hline Thailand & $105,63 \%$ & $112,94 \%$ & $135,12 \%$ & $129,08 \%$ & $130,87 \%$ & $123,11 \%$ \\
\hline Vietnam & $125,99 \%$ & $136,38 \%$ & $148,77 \%$ & $147,97 \%$ & $154,79 \%$ & $160,96 \%$ \\
\hline
\end{tabular}

Source: Author's calculations from IFS data.

The market portfolio's exchange rate exposure of the six Southeast Asian countries was assessed by estimating coefficients of an NER variable. For example, a $1 \%$ increase in the nominal exchange rate (USD gains value against local currency) reduced the average regional stock returns by $1.043651 \%$ and vice versa. This is similar to the results shown in the studies of Lin (2011), Tsai (2012), and Al-Shboul and Anwar (2014), in which the time-series data regression approaches were employed to find the negative relationship between the exchange rate risk and the stock returns. This influence could be explained from the fact that the value of net foreign assets in the selected countries in the 2009-14 period increased continuously (Figure 2). During this period, any rise in the money supply could cause a high inflation in Southeast Asia. With the downward trend of the local currency, the macroeconomic situation of those countries was troubled by the rise of import costs. This led to the capital flight from the region and adverse impacts on the foreign debt position as well as the business and stock market. 


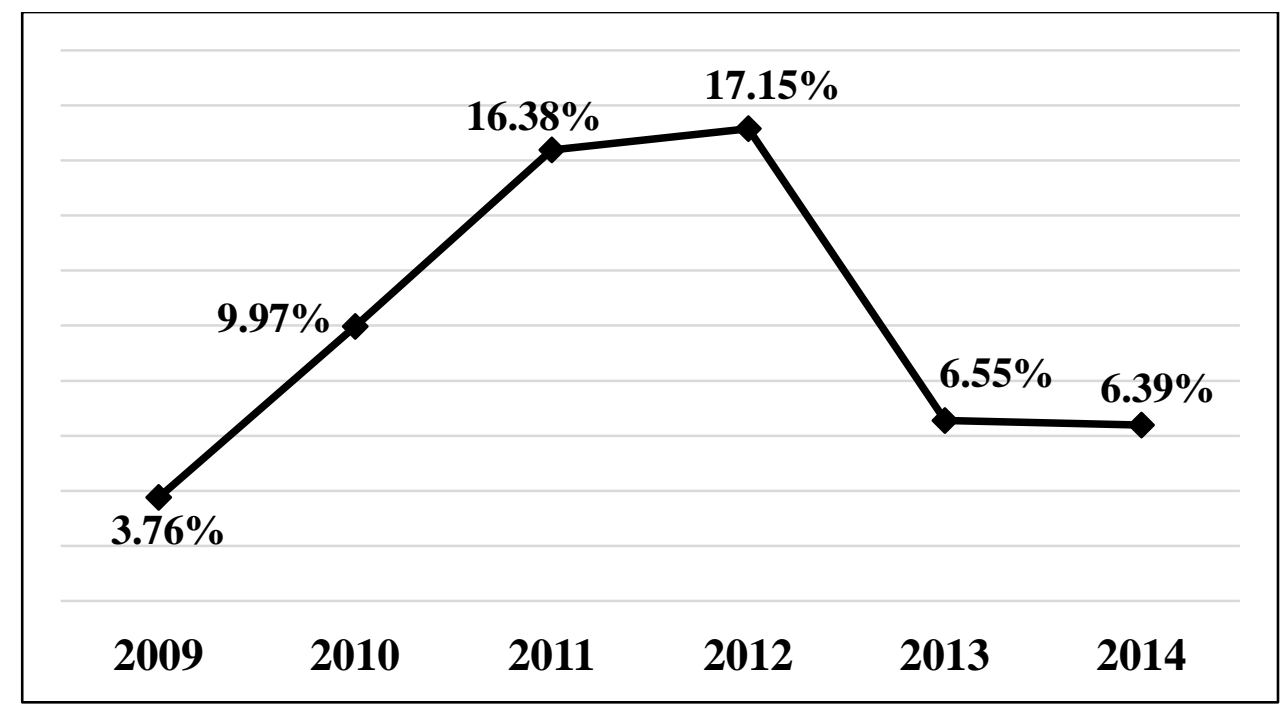

Figure 2. The average growth rate in the value of net foreign assets (NFA) of six Southeast Asian countries from 2009 to 2014

Source: Author's calculations from IFS data.

Another important issue needed to be considered is the status of liability dollarisation. When a government and enterprises borrow foreign debts in forms of soft loans, commercial loans or bonds, they must be denominated in foreign currencies, mainly USD. According to ADB, the external debt statistics of the six Southeast Asian countries raised considerably from 415.16 billion USD in 2009 to 613.59 billion USD in 2013 while the value of the ASEAN domestic bond market (with an annual average growth of approximate $43.31 \%$ ) was only 172.16 billion USD in 2013. It is obvious that the domestic bond market was relatively small, compared to the volume of foreign currency debt. This result is consistent with the conclusion from Lin (2011) about the phenomenon of liability dollarisation in emerging markets. They are also the countries in which production was based on import materials while the enterprises disrespected the currency hedging. Therefore, the excessive local currency decreases against dollars caused negative influence on the value of items in the balance sheets and income statements of enterprises and, consequently, resulted in falling stock returns.

The estimated coefficient of the interaction variable ( $D * N E R$ ) was found as 0.4855249 and statistically significant at $10 \%$ level. This indicates the existence of asymmetric exchange rate exposure in Southeast Asia. Each $1 \%$ appreciation of nominal exchange rate (local currency depreciation) would cause an average $0.486 \%$ rise in the local market returns whilst a $1 \%$ depreciation would not lead to any changes in the market returns. As mentioned earlier, the trade and international investment of the Southeast Asian countries were heavily dependent on external markets. Thus, the local currency tended to decrease and facilitated the export 
activities. The enterprises therefore focused on constructing hedging strategies by applying operational techniques (such as rebalancing foreign currency denominated revenues and costs), thereby increasing the intensity of intra-regional trade and using derivative instruments.

\subsubsection{Exchange rate exposure with bilateral real exchange rate}

Table 7. Regression results of equation (5) by GLS

\begin{tabular}{|l|c|c|c|c|}
\hline \multicolumn{1}{|c|}{ Variable } & Beta coefficient & Standard error & z-statistic & p-value \\
\hline MSCIACWI & $0.460589^{* * *}$ & 0.045673 & 10.08 & 0.000 \\
\hline RER & $-0.90453^{* * *}$ & 0.183925 & -4.92 & 0.000 \\
\hline D*RER & $0.557912^{* *}$ & 0.267152 & 2.09 & 0.037 \\
\hline Constant & $0.005586^{* *}$ & 0.002706 & 2.06 & 0.039 \\
\hline
\end{tabular}

Notes: t-statistic values are shown in parentheses; ***, **, and *, respectively, denote significance at the 1\%, 5\%, and 10\% level.

Table 7 displays the regression results of equation (5) after using the GLS model to deal with the heteroskedasticity. These obtained results are similar to the exposure assessed by the nominal exchange rate (the regression coefficient signs of Table 5 and Table 7 were the same). Specifically, the asymmetry exchange rate exposure persists with the estimated coefficients of the interaction variable ( $D * R E R$ ) of 0.557912 (compared to the results in Table 5, the degree of asymmetry exposure was larger than that measured by the real exchange rate). The real depreciation in the local currency lessened the domestic market portfolio returns (regression coefficient of RER is negative) due to its dependence on the capital inflows from foreign markets, though it helped to improve the export situation. This is worth noting in the operating exchange rate policy of the central bank of the Southeast Asian countries.

\subsubsection{Robustness checks}

\subsubsection{Exchange rate exposure and exchange rate regime}

From 2009, the six Southeast Asian countries followed various exchange rate regimes (Table 8). Following the annual IMF report on exchange arrangements, it is possible to divide them into two groups. The first group includes Indonesia, Philippines and Thailand pursuing the floating system, while the second group includes Malaysia, Singapore and 
Vietnam having an important impact in controlling the exchange rate. In fact, a predictable intervention of a central bank on its currency's value can reduce and eliminate impacts of exchange rate risk to stock returns.

Table 8. Exchange rate regime of Southeast Asian countries in the period 2009-2014

\begin{tabular}{|l|l|l|l|l|l|l|}
\hline Country & $\mathbf{2 0 0 9}$ & \multicolumn{1}{|c|}{$\mathbf{2 0 1 0}$} & \multicolumn{1}{|c|}{$\mathbf{2 0 1 1}$} & \multicolumn{1}{|c|}{$\mathbf{2 0 1 2}$} & \multicolumn{1}{|c|}{$\mathbf{2 0 1 3}$} & \multicolumn{2}{|c|}{2014} \\
\hline Indonesia & Floating & Floating & Floating & Floating & $\begin{array}{l}\text { Crawl-like } \\
\text { arrangement }\end{array}$ & Floating \\
\hline Malaysia & Floating & $\begin{array}{l}\text { Other } \\
\text { managed }\end{array}$ & $\begin{array}{l}\text { Other } \\
\text { managed }\end{array}$ & $\begin{array}{l}\text { Other } \\
\text { managed }\end{array}$ & $\begin{array}{l}\text { Other } \\
\text { managed }\end{array}$ & $\begin{array}{l}\text { Other } \\
\text { managed }\end{array}$ \\
\hline Philippines & Floating & Floating & Floating & Floating & Floating & Floating \\
\hline Singapore & Floating & $\begin{array}{l}\text { Other } \\
\text { managed }\end{array}$ & $\begin{array}{l}\text { Other } \\
\text { managed }\end{array}$ & $\begin{array}{l}\text { Other } \\
\text { managed }\end{array}$ & $\begin{array}{l}\text { Crawl-like } \\
\text { arrangement }\end{array}$ & $\begin{array}{l}\text { Stabilized } \\
\text { arrangement }\end{array}$ \\
\hline Thailand & Floating & Floating & Floating & Floating & Floating & Floating \\
\hline Vietnam & $\begin{array}{l}\text { Other } \\
\text { managed }\end{array}$ & $\begin{array}{l}\text { Stabilized } \\
\text { arrangement }\end{array}$ & $\begin{array}{l}\text { Stabilized } \\
\text { arrangement }\end{array}$ & $\begin{array}{l}\text { Stabilized } \\
\text { arrangement }\end{array}$ & $\begin{array}{l}\text { Stabilized } \\
\text { arrangement }\end{array}$ & $\begin{array}{l}\text { Stabilized } \\
\text { arrangement }\end{array}$ \\
\hline
\end{tabular}

Source: IMF Annual report on Exchange Arrangements and Exchange Restrictions 2009-14.

Hence, this study further investigated whether the central bank's foreign exchange intervention through the exchange rate system could affect exchange rate exposure or not. The estimate equations (4) and (5) were then used with the sub samples from three countries, Malaysia, Singapore and Vietnam.

The results presented in Table 9 show that in this group of three countries, the exchange rate exposure still existed. The local currency depreciation lowered the average market portfolio returns (the regression coefficients for the NER and RER variables were -0.6396 and 0.5216 , respectively, and statistical significance at $5 \%$ level although they were smaller than the ones in the full analysis). However, the asymmetric exposure was not significant. This was because the exchange rate hedging became easier when the central bank managed the exchange rate fluctuation. Both importers and exporters were flexible in offsetting cash flow denominated in foreign currency. Consequently, in the managed exchange rate regime, the exchange rate exposure was reduced but could not be eliminated completely. Therefore, the importance of currency hedging as well as the required risk premium in 
the financial assets valuation still need to be considered even the exchange rate arrangement has managed.

Table 9. Regression results of equation (4) and (5) by GLS with three Southeast Asia country sample

\begin{tabular}{|l|c|c|c|c|}
\hline \multirow{2}{*}{ Variable } & \multicolumn{2}{|c|}{ Equation (4) } & \multicolumn{2}{c|}{ Equation (5) } \\
\cline { 2 - 5 } & Beta coefficient & z-statistic & Beta coefficient & z-statistic \\
\hline MSCIAWCI & $0.3037252^{* * *}$ & 4.57 & $0.3161919^{* * *}$ & 4.74 \\
\hline NER & $-0.6396316^{* *}$ & -2.13 & & \\
\hline D*NER & 0.1010969 & 0.24 & & -1.76 \\
\hline RER & & & $-0.521584^{*}$ & 0.2 \\
\hline D*RER & & & 0.0831276 & 2.14 \\
\hline Constant & $0.0093235^{* * *}$ & 2.37 & $0.0086691^{* * *}$ & \\
\hline
\end{tabular}

Notes: ${ }^{* * *},{ }^{*}$, and $*$, respectively, denote significance at the $1 \%, 5 \%$, and $10 \%$ level.

\subsubsection{Endogeneity problem}

By using only one domestic macroeconomic variable as exchange rate change in equations (4) and (5), it could lead to endogeneity problems by omitting variables and, therefore, affect the model consistency. In order to solve this problem, these two equations were regressed using the GMM for the panel data (proposed by Arellano Bond (1991)). To estimate this model, the one-period-lagged value of the dependent variable was added. The instrument variables were the one-period-lagged values of the changing in exchange rate variable and the interaction variable. The regression results are presented in Table 10. 
Table 10. Regression results of equation (4) and (5) by GMM

\begin{tabular}{|c|c|c|c|c|}
\hline \multirow{2}{*}{ Variable } & \multicolumn{2}{|c|}{ Equation (4) } & \multicolumn{2}{|c|}{ Equation (5) } \\
\hline & Beta coefficient & z-statistic & Beta coefficient & z-statistic \\
\hline INDEX(-1) & $0.091403 * * *$ & 2.84 & $0.109415^{* * *}$ & 3.29 \\
\hline MSCIACWI & $0.374098 * * *$ & 4.22 & $0.407148 * * *$ & 4.43 \\
\hline NER & $-1.15592 * * *$ & -4.39 & & \\
\hline D*NER & $0.543249 *$ & 1.94 & & \\
\hline RER & & & $-0.91701 * * *$ & -5.08 \\
\hline D*RER & & & $0.439604^{* *}$ & 2.44 \\
\hline Constant & $0.006559 * *$ & 2.23 & $0.004999 * *$ & 1.99 \\
\hline Sargan test & Chi-Sq. Statistic: & 364.5486 & Chi-Sq. Statistic: = & 66.4912 \\
\hline
\end{tabular}

Notes: ${ }^{* *}, * *$, and ${ }^{*}$, respectively, denote significance at the $1 \%, 5 \%$, and $10 \%$ level.

Sargan test's value about over-identifying restrictions allowed us to accept the null hypothesis. It means that the instrument variable was suitable. The GMM regression results affirm the presence of the asymmetric exchange rate exposure with signs of correlation coefficients and the statistical significance level was similar to the results from the GLS regression. The strong linkage between stock prices and exchange rates always occurred and the asymmetric exposure could be considered a notable finding for investors, entrepreneurs and authorities.

\section{Conclusion}

This study has investigated the influence of exchange rate fluctuations on the stock market returns of the six representative countries of Southeast Asia. To achieve this objective, we estimated the model to identify the exchange rate exposure and assessed whether the asymmetry existed or not. The exchange rate changes were detected by the nominal exchange rate and the real exchange rate to exclude the effects of high inflation in Southeast Asia. We documented that exchange rate exposure existed during the research period. Specifically, the stock returns of the domestic securities portfolio decreased as the local currency depreciated against the US dollar. This result is consistent with the phenomenon of liability dollarisation as well as the continuous increase of the net foreign assets positioning constantly in the emerging markets, as mentioned in the previous studies. A valuable finding from the regression results was the 
presence of asymmetric exchange rate exposure. One important reason was that the net export position of the countries in Southeast Asia was positively impacted by the real depreciation of local currency. Moreover, this downtrend also motivated companies to seek resources by increasing intra-regional trade and taking full advantage of the Asian Economic Community (AEC) formed in late 2015.

International integration is the inevitable trend, and leads to the challenges facing financial assets valuation. Southeast Asian firms should construct an appropriate currency risk management strategy regardless of the central banks commit to peg their currency's value. This will require the development of a derivatives market to provide modern techniques as well as to build a culture of risk management for firms. The increase in the size of the domestic bond market also provides a positive direction to help constrain the dependence on funding in foreign currency and, simultaneously, limit long-term exchange rate exposure for business.

\footnotetext{
' JCI INDEX, KLCI INDEX, PSEI INDEX, ST INDEX, SET INDEX and VNINDEX are stock market indexes of Indonesia, Malaysia, Philippines, Singapore, Thailand and Vietnam, respectively.
} 


\section{References}

Alder, M., and Dumas, B. (1984), 'Exposure to currency risk: definition and measurement', Financial Management, 13, 41-50

Al-Shboul, M., and Anwar, S. (2014), 'Foreign exchange rate exposure: Evidence from Canada', Review of Financial Economics, 23, 18-29

Arellano, M., and Bond, S. (1991), 'Some tests of specification for panel data: Monte carlo evidence and an application to employment equations', Review of Economic Studies, 58, 277-97

Baltagi, B. (2008), Econometric Analysis of Panel Data, PLACE: John Wiley \& Sons

Bartram, S., and Bodnar, G. (2012), 'Crossing the lines: The conditional relation between exchange rate exposure and stock returns in emerging and developed markets', Journal of International Money and Finance, 31, 766-92

Bekaert, G., and Harvey, C. (1995), 'Time varying world market integration', Journal of Finance, 50 (2), 403-44

Chkili, W., Aloui, C., and Nguyen, D. (2012), 'Asymmetric effects and long memory in dynamic volatility relationships between stock returns and exchange rates', Journal of International Financial Markets, Institutions \& Money, 22, 738-57

Chue, T., and Cook, D. (2008), 'Emerging market exchange rate exposure', Journal of Banking \& Finance, 32, 1349-62

Hekman, C. (1983), 'Measuring Foreign Exchange Exposure: A Practical Theory and Its Application', Financial Analysts Journal, 39 (5), 59-65

Hsiao, C. (1986), Analysis of Panel Data, Cambridge: Cambridge University Press

Im, K., Pesaranb, M., and Shin, Y. (2003), 'Testing for unit roots in heterogeneous panels', Journal of Econometrics, 115 (1), 53-74

Koutmos, G., and Martin, A. (2003). 'Asymmetric exchange rate exposure: theory and evidence', Journal of International Money and Finance, 22 (3), $365-83$

Levin, A., Lin, C. F., and Chu, C. S. (2002), 'Unit root tests in panel data: Asymptotic and finite-sample properties', Journal of Econometrics 108, 124

Lin, C. H. (2011), 'Exchange rate exposure in the Asian emerging markets', Journal of Multinational Financial Management, 224-38 
Tsai, I. C. (2012), 'The relationship between stock price index and exchange rate in Asian markets: A quantile regression approach', Journal of International Financial Markets, Institutions \& Money, 22, 609-21

Ye, M., Hutson, E., and Muckley, C. (2014), 'Exchange rate regimes and foreign exchange exposure: The case of emerging market firms', Emerging Markets Review, 21, 156-82

To cite this article:

Minh, L., Ha, H., \& Hong, D., (2017). Asymmetric Exchange Rate Exposure Research in Southeast Asian Countries. Exchanges: The Warwick Research Journal, 4(2), 262-279. Retrieved from:

http://exchanges.warwick.ac.uk/index.php/exchanges/article/view/141 